\title{
Correction to: Comparative genomics of the wheat fungal pathogen Pyrenophora tritici- repentis reveals chromosomal variations and genome plasticity
}

Paula Moolhuijzen ${ }^{1 *}$, Pao Theen See ${ }^{1}$, James K. Hane ${ }^{1}$, Gongjun Shi ${ }^{2}$, Zhaohui Liu ${ }^{2}$, Richard P. Oliver ${ }^{1}$ and Caroline S. Moffat ${ }^{1}$

\section{Correction}

Following publication of the original article [1], the author flagged the following errors:

1. All occurrences of "11,137" should be "11137". This is the name of an isolate.

2. URL link "https://downloads.bioplatforms.com/ wheat_pathogens/" on page 15 is not working, please use "https://data.bioplatforms.com/ organization/bpa-wheat-pathogens-genomes"

3. URL link "https://downloads.bioplatforms.com/ wheat_pathogens_transcript" on page 16 is not working, please use "https://data.bioplatforms.com/ organization/about/bpa-wheat-pathogenstranscript"

4. One occurrence of "In vivo" on page 16 should be "In vitro" and italicized.

5. One occurrence of "Codon Quarry v1.2" on page 17 should be "Coding Quarry v1.2"

6. One occurrence of "F129 L" has a space inserted on page 6 and should be "F129L"

7. One occurrence of "F129 T" has a space inserted on page 6 and should be "F129T"

\section{Author details}

${ }^{1}$ Centre for Crop Disease and Management, Department of Environment and Agriculture, Curtin University, Bentley, Western Australia, Australia.

2Department of Plant Pathology, North Dakota State University, Fargo, ND, USA.
Received: 30 August 2018 Accepted: 7 September 2018 Published online: 13 September 2018

\section{Reference}

1. Moolhuijzen et al. Comparative genomics of the wheat fungal pathogen Pyrenophora tritici-repentis reveals chromosomal variations and genome plasticity BMC Genomics (2018). 19:279 DOI: https://doi.org/10.1186/s12864018-4680-3

\footnotetext{
* Correspondence: Paula.Moolhuijzen@curtin.edu.au

${ }^{1}$ Centre for Crop Disease and Management, Department of Environment and Agriculture, Curtin University, Bentley, Western Australia, Australia

Full list of author information is available at the end of the article
}

(c) The Author(s). 2018 Open Access This article is distributed under the terms of the Creative Commons Attribution 4.0 International License (http://creativecommons.org/licenses/by/4.0/), which permits unrestricted use, distribution, and reproduction in any medium, provided you give appropriate credit to the original author(s) and the source, provide a link to the Creative Commons license, and indicate if changes were made. The Creative Commons Public Domain Dedication waiver (http://creativecommons.org/publicdomain/zero/1.0/) applies to the data made available in this article, unless otherwise stated. 